\title{
Excitation of Ventral Tegmental Area Dopaminergic and Nondopaminergic Neurons by Orexins/Hypocretins
}

\author{
Tatiana M. Korotkova, Olga A. Sergeeva, Krister S. Eriksson, Helmut L. Haas, and Ritchie E. Brown \\ Institut für Neurophysiologie, Heinrich-Heine-Universität, D-40001 Düsseldorf, Germany
}

Orexins/hypocretins are involved in mechanisms of emotional arousal and short-term regulation of feeding. The dense projection of orexin neurons from the lateral hypothalamus to mesocorticolimbic dopaminergic neurons in the ventral tegmental area (VTA) is likely to be important in both of these processes.

We used single-unit extracellular and whole-cell patch-clamp recordings to examine the effects of orexins (A and B) and melaninconcentrating hormone $(\mathrm{MCH})$ on neurons in this region. Orexins caused an increase in firing frequency $\left(\mathrm{EC}_{50} 78 \mathrm{nM}\right)$, burst firing, or no change in firing in different groups of A10 dopamine neurons. Neurons showing oscillatory firing in response to orexins had smaller afterhyperpolarizations than the other groups of dopamine neurons. Orexins (100 nM) also increased the firing frequency of nondopaminergic neurons in the VTA. In the presence of tetrodotoxin $(0.5 \mu \mathrm{M})$, orexins depolarized both dopaminergic and nondopaminergic neurons, indicating a direct postsynaptic effect. Unlike the orexins, $\mathrm{MCH}$ did not affect the firing of either group of neurons. Single-cell PCR experiments showed that orexin receptors were expressed in both dopaminergic and nondopaminergic neurons and that the calcium binding protein calbindin was only expressed in neurons, which also expressed orexin receptors.

In narcolepsy, in which the orexin system is disrupted, dysfunction of the orexin modulation of VTA neurons may be important in triggering attacks of cataplexy.

Key words: dopamine; GABA; hypocretin; melanin concentrating hormone; narcolepsy; orexin; reward; whole-cell

\section{Introduction}

Ventral tegmental area (VTA) dopaminergic and GABAergic neurons are critically involved in brain mechanisms of reward, reinforcement, and emotional arousal (Wise and Rompre, 1989). A10 dopamine neurons project from the VTA to the nucleus accumbens, amygdala, hippocampus, and prefrontal cortex, forming the mesocorticolimbic dopamine system (Albanese and Minciacchi, 1983). VTA GABAergic neurons also project to the prefrontal cortex and regulate the activity of VTA dopamine neurons via local axon collaterals (Steffensen et al., 1998). The firing of dopamine neurons in this region is closely correlated with the availability of primary rewards (food, water, and sex) (Schultz, 1998). Activation of VTA neurons initiates locomotor activity to obtain such primary rewards, and this activation is associated with a high level of arousal; compounds, which block the dopamine transporter, leading to enhanced dopaminergic tone in target regions, are potent wake-promoting substances (Wisor et al., 2001).

The VTA receives a massive input from the lateral hypothalamic area, including projections from neurons containing the

\footnotetext{
Received Aug. 27, 2002; revised 0ct. 11, 2002; accepted 0ct. 16, 2002.

This work was supported by a grant from the Medical Faculty of the Heinrich-Heine University (R.E.B). We thank Dr. Robert McCarley, Dr. Mahesh Thakkar, and Dr. Radhika Basheer for helpful comments on this manuscript and Claudia Wittrock and Annette Scherer for excellent technical assistance.

Correspondence should be addressed to Tatiana Korotkova, Institut für Neurophysiologie, Heinrich-HeineUniversität, Universitätsstrasse 1, D-40001, Düsseldorf, Germany. E-mail: tatiana.korotkova@uni-duesseldorf.de.

R. E. Brown's present address: Department of Psychiatry, Harvard Medical School and Veterans Affairs Medical Center, 940 Belmont Street, Research 151-C, Brockton, MA 02301.

Copyright $\odot 2002$ Society for Neuroscience $\quad 0270-6474 / 02 / 220007-\bullet \$ 15.00 / 0$
}

neurotransmitters orexin A and orexin B (Fadel and Deutch, 2002). Recent evidence has shown that loss of orexin neurons or mutation of the orexin 2 receptor causes the sleep disorder narcolepsy (Willie et al., 2001). Central injection of orexin A, which activates both orexin receptors with high affinity, potently enhances arousal and locomotor activity, as well as causes a shortlasting increase in feeding (Willie et al., 2001). VTA neurons are likely to be involved in both the physiological and pathophysiological roles of orexins. The hyperlocomotion and stereotypy induced by intracerebroventricular orexin application are blocked by dopamine receptor antagonists, and orexins increase intracellular calcium in acutely isolated A10 dopamine neurons (Nakamura et al., 2000). The excessive daytime sleepiness of narcoleptics is currently treated with amphetamine-like compounds, which enhance extracellular dopaminergic levels (Nishino and Mignot, 1997; Wisor et al., 2001). Furthermore, application of dopamine $\mathrm{D}_{2}$ receptor agonists either systemically or locally into the VTA exacerbates cataplexy (periods of muscle weakness triggered by emotional stimuli in narcoleptics), whereas $\mathrm{D}_{2}$ receptor antagonists have the opposite effect (Reid et al., 1996; Okura et al., 2000). In narcoleptic canines, the presentation of food, one of the stimuli that potently activates VTA dopamine neurons, is an extremely effective trigger for cataplexy (Nishino and Mignot, 1997). Here we describe the effects of orexins on dopaminergic and nondopaminergic neurons in the VTA.

Parts of this paper have been published previously in abstract form (Korotkova et al., 2001). 


\section{Materials and Methods}

Slice preparation and electrophysiology. Coronal brain slices were prepared from 3- to 4-week-old male Wistar rats as described previously (Korotkova et al., 2002). Slices ( $400 \mu \mathrm{m}$ thick) were cut at the level of the rostral VTA using a vibroslicer (Campden Instruments, Loughborough, UK). After slicing, they were placed into artificial CSF (ACSF) [containing (in mM) $124 \mathrm{NaCl}, 3.7 \mathrm{KCl}, 25.6 \mathrm{NaHCO}_{3}, 1.24 \mathrm{NaH}_{2} \mathrm{PO}_{4}, 2 \mathrm{CaCl}_{2}$, $1.3 \mathrm{MgSO}_{4}$, and 10 glucose], saturated with $95 \% \mathrm{O}_{2}-5 \% \mathrm{CO}_{2}$ for $\geq 1 \mathrm{hr}$ at room temperature before being transferred to the recording chamber at $32^{\circ} \mathrm{C}$, in which they were constantly perfused with the same ACSF at a flow rate of $1 \mathrm{ml} / \mathrm{min}$.

Extracellular recordings were obtained using glass microelectrodes filled with $2 \mathrm{M} \mathrm{NaCl}$ (resistance of 5-10 M $\Omega$ ). Positioning of the electrode was controlled with a dissecting microscope using the accessory optic tract as a marker, which is the border between the substantia nigra and VTA. Signals were recorded using an Axoclamp 2A or 2B amplifier (Axon Instruments, Foster City, CA), filtered between 0.5 and $10 \mathrm{kHz}$, sampled at $20 \mathrm{kHz}$, and analyzed with pClamp8 software (Axon Instruments). The frequency of extracellular action potentials was determined online in bins of $15 \mathrm{sec}$ duration.

Whole-cell patch-clamp recordings were made "blindly." Patch pipettes (3-6 M $\Omega$ ) were pulled from borosilicate glass (GB150F-8P; Science Products, Hofheim, Germany) and filled with an intracellular solution containing: $135 \mathrm{~mm}$ potassium gluconate, $5 \mathrm{~mm} \mathrm{NaCl}, \mathrm{MgCl}_{2}, 10 \mathrm{~mm}$ HEPES, 0.1 mm EGTA, 2 mm Na 2 ATP, 0.5 mm NaGTP 0.5, 0.5\% biocytin, $\mathrm{pH}$ 7.25, with $\mathrm{KOH}, 280 \mathrm{mOsm}$. Signals were recorded using an Axoclamp 2B amplifier (Axon Instruments). Membrane potential measurements were adjusted for a $-15 \mathrm{mV}$ liquid junction potential between pipette and bath solutions (calculated using pClamp8 Software; Axon Instruments). Series resistance was $<50 \mathrm{M} \Omega$ (and was similar in cells showing different responses to orexins); bridge balance was continuously maintained during current-clamp experiments. Continuous recordings of membrane voltage were made using a Gould TA550 chart recorder (Gould Electronics, Cleveland, $\mathrm{OH}$ ).

Drugs and statistics. Drugs used were as follows: orexin A and B (Bachem, Heidelberg, Germany), melanin-concentrating hormone $(\mathrm{MCH})$ (Bachem), quinpirole (Research Biochemicals, Natick, MA), dopamine (Sigma, Deisenhofen, Germany), and DAMGO (Tyr-D-Ala-GlyNMe-Phe-Gly-ol) (Tocris Cookson, Bristol, UK). All other chemicals were obtained from Merck (Darmstadt, Germany). DAMGO was dissolved in DMSO (final bath concentration of DMSO was $0.1 \%$; this concentration of DMSO did not affect the membrane potential of cells). Drugs were bath applied. Statistical analysis was performed with Student's $t$ test (unpaired) and $\chi^{2}$ test. Data are presented as mean \pm SEM.

Immunocytochemistry. After recording, slices were fixed in $4 \%$ paraformaldehyde in $0.1 \mathrm{M}$ phosphate buffer (PB), $\mathrm{pH} 7.4 \mathrm{n}$ for $4-8 \mathrm{hr}$, cryoprotected in $\mathrm{PB}$ with $30 \%$ sucrose, and cryosectioned at $40 \mu \mathrm{m}$ thickness. Sections were mounted on gelatin-coated slides, dried, and stained according to the immunofluorescence staining protocol. The sections were first washed in PBS with $0.25 \%$ Triton X-100 (PBS-T) for 5 min and then preincubated with $2 \%$ normal goat serum in PBS-T for $30 \mathrm{~min}$ at room temperature. This solution was also used to dilute a mouse monoclonal antibody against tyrosine hydroxylase (TH) (Sigma) to 1:500. This antibody solution was applied to the sections for $12-16 \mathrm{hr}$ at $4^{\circ} \mathrm{C}$. After washing, sections were incubated with Alexa Fluor 488-labeled goat antimouse IgG (1:500; Molecular Probes, Eugene, OR) to reveal the TH immunoreactivity and Texas Red-streptavidin (1:200; Molecular Probes) to stain biocytin-filled neurons, for $90 \mathrm{~min}$ at room temperature.

Acute isolation of VTA neurons and single-cell reverse transcriptionPCR. For preparation of isolated cells, the VTA was dissected from the slice and incubated with papain (Sigma) in crude form $(0.3-0.5 \mathrm{mg} / \mathrm{ml}$ ) for $20 \mathrm{~min}$ at $37^{\circ} \mathrm{C}$. The cytoplasm was taken for reverse transcription (RT)-PCR as described by Eriksson et al. (2001). Protocols of the RT reaction and PCR amplification were similar to those described previously (Vorobjev et al., 2000). A two-round amplification strategy was used in each protocol. The following primers were used (from $5^{\prime}$ to $3^{\prime}$ ): $\mathrm{TH}$, (sense) GCTGTCACGTCCCCAAGGTT, (antisense) AAGCGCACAAAATACTCCAGG, and (antisense2, for the second round) CAGC-
CCGAGACAAGGAGGAG (size of the product was 220 bp). For PCR analysis of GAD expression in the first round of amplification, the degenerated antisense primer (CCCCAAGCAGCATCCACAT) was taken either with GAD65 cDNA-specific sense primer (TCTTTTCTCCTGGTGGTGCC) or with GAD67 cDNA-specific sense primer (TACGGGGTTCGCACAGGTC). For the second round, the same sense primers were used in combination with specific antisense primers: CAGTGGTTCCAGCTGTGGC for GAD65 and CGGTTGCATTGACATAAAGGG for GAD67. Primers designed to recognize orexin receptors were described previously (Eriksson et al., 2001). Primers for the first amplification of calbindin (CB) and neuropeptide Y (NPY) were described by Cauli et al. (1997); for the $2 \mathrm{~d}$ amplification, the same lower primers were used in combination with CB (sense2, TCCTGCTGCTCTTTCGATGC; size of product was $303 \mathrm{bp}$ ) or NPY (sense2, GCTCGTGTGTTTGGGCATTCT; $251 \mathrm{bp}$ ). The identity of cDNA sequences was revealed by sequencing the second-round amplification products, performed as described by Vorobjev et al. (2000). The thin-walled PCR tubes contained a mixture of first-strand cDNA template $(1.1 \mu \mathrm{l}), 10 \times$ PCR buffer $(5 \mu \mathrm{l}), 10$ pM each of sense and antisense primer, and $200 \mu \mathrm{M}$ each of dNTP, and $2.5 \mathrm{U}$ of Taq polymerase. The final reaction volume was adjusted to $50 \mu \mathrm{l}$ with nuclease-free water (Promega, Madison, WI). $\left[\mathrm{Mg}^{2+}\right]$ was $2.5 \mathrm{~mm}$ for all reactions. Taq enzyme, PCR buffer, $\mathrm{Mg}^{2+}$ solution, and four dNTPs were purchased from Qiagen (Erkrath, Germany). Oligonucleotides were synthesized by MWG Biotech (Ebersberg, Germany), and amplification was performed on a thermal cycler (GenAmp 9600; PerkinElmer Life Sciences, Weiterstadt, Germany). In each round, 35 cycles of the following thermal programs were used: denaturation at $94^{\circ} \mathrm{C}$ for $48 \mathrm{sec}$, annealing at $53^{\circ} \mathrm{C}$ for $1 \mathrm{~min}$, and extension at $72^{\circ} \mathrm{C}$ for $90 \mathrm{sec}$. For the second amplification round, $1 \mu \mathrm{l}$ of product from the first amplification was used as a template.

\section{Results}

\section{Whole-cell and single-unit recordings in slices}

To characterize the effect of orexins on VTA neurons, we performed whole-cell current-clamp recordings in slices. Cells were filled with biocytin by diffusion from the patch pipette and identified post hoc by staining for TH. To ensure that orexin effects on neuronal firing were not an artifact of dialysis of the cells, the effects of orexins were also investigated using extracellular singleunit recordings.

\section{Electrophysiological characterization of the recorded neurons}

The double stainings revealed that recordings were made from TH-positive cells $(n=14)$ (Fig. $1 A)$, which are assumed to be dopaminergic cells, and TH-negative cells $(n=6)$ (Figs. $2 A, 3 A)$, which are presumed to be GABAergic neurons. They differed in a number of characteristics, as described previously (Grace and Onn, 1989): spike duration was significantly broader in dopaminergic neurons $(n=14)$ than in GABAergic neurons $(3.3 \pm 0.13$ vs $1.68 \pm 0.23 \mathrm{msec} ; p<0.0005)$, and spike thresholds were more positive in dopaminergic than in GABAergic cells $(-44.7 \pm 1.4$ and $-50.8 \pm 0.7 \mathrm{mV} ; p<0.05)$. Dopamine cells possessed a prominent $I_{\mathrm{h}}$ current (Fig. $1 B$ ). $I_{\mathrm{h}}$ sag, measured as the percentage reduction from the peak at the end of a 1-sec-long step elicited by a $-400 \mathrm{pA}$ current injection, was $33.1 \pm 3.4 \%$. In GABAergic cells, a $-300 \mathrm{pA}, 1$ sec step led to a similar amount of peak hyperpolarization, but the $I_{\mathrm{h}}$ sag at the end of it amounted to only $5.0 \pm 0.2 \%$. The dopamine cells had an average firing frequency of $2.86 \pm 0.32 \mathrm{~Hz}$; burst firing or spontaneous alterations in firing rate were never observed in control cells. The GABAergic cells could be divided into two groups according to their firing rate. One group fired at a relatively high frequency: $8.7 \pm 2.2 \mathrm{~Hz}$ $(n=3)$ (Fig. $2 B)$. The second group consisted of slow-firing cells: $0.63 \pm 0.3 \mathrm{~Hz}(n=4)$ (Fig. $3 B)$. Both groups of cells fired at high frequency $(>30 \mathrm{~Hz})$ during depolarizing current steps. Cells in 
A

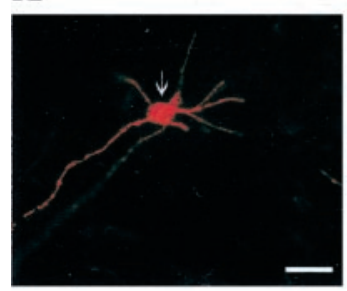

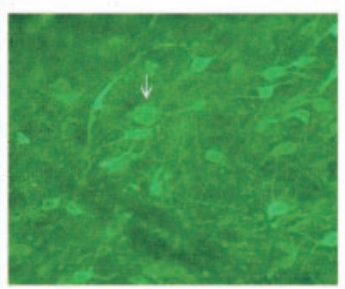

B

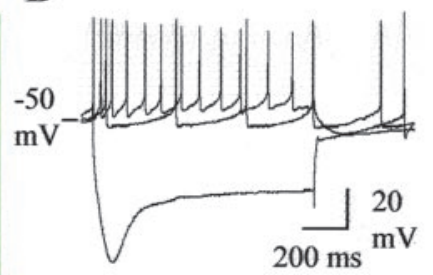

C

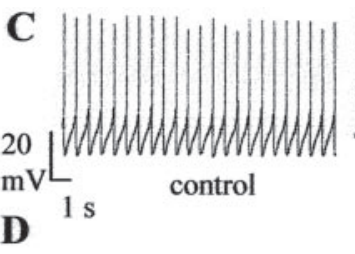

$-41.0-$ $-45.0$ $\mathrm{mV}$

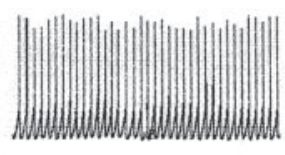

Orexin A
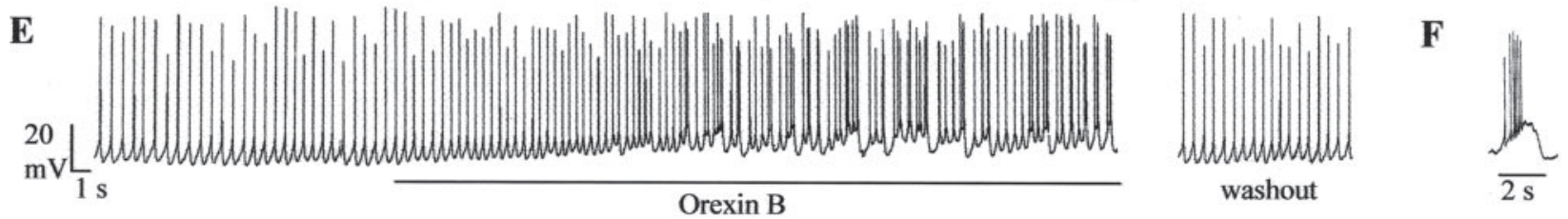

Figure 1. Electrophysiological properties of dopaminergic neurons and their response to orexins. $A$, Double stainings of biocytin-filled neuron (red) and TH-immunoreactive neurons (green). Arrows indicate the position of the neuron in the tissue. This biocytin-filled neuron is TH positive. Scale bar, $50 \mu \mathrm{m} . B$, Voltage responses to current pulses $(-0.4,0,+0.1 \mathrm{pA})$. C, Chart recording of membrane potential and spontaneous action potentials before and after application of orexin $A(100 \mathrm{~nm})$. Orexin A was applied for 2 min. $D, 0$ rexin $B(100 \mathrm{~nm})$ caused depolarization in the presence of tetrodotoxin $(0.5 \mu \mathrm{m})$. E, Example of a TH-positive neuron in which application of orexin B (100 nм) caused burst firing. $F$, A typical orexin-mediated burst.

A
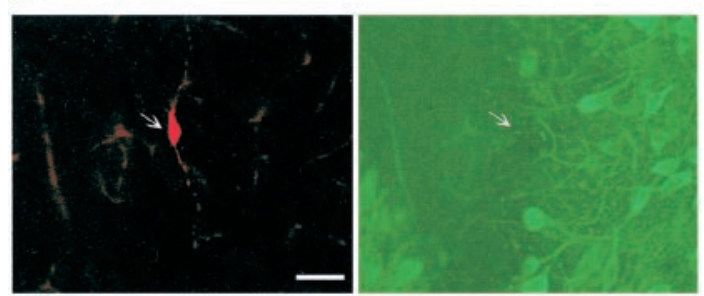

B
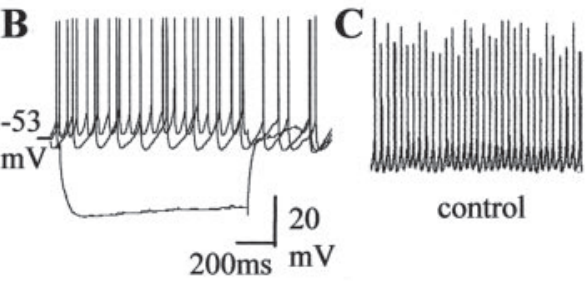

control

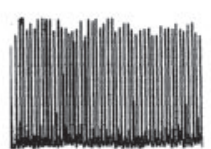

Orexin B 20

D $-45.0-$ $-50.5$ $\mathrm{mV}$

$1 \mathrm{~s}$

$\mathbf{A}$

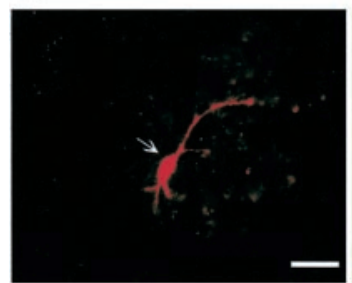

B

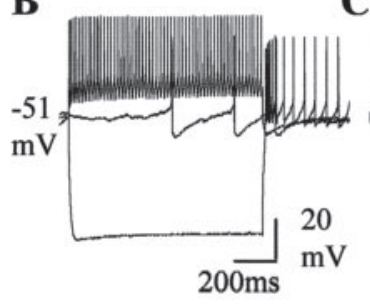

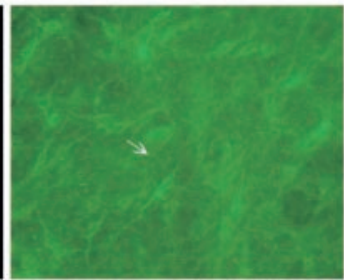

C

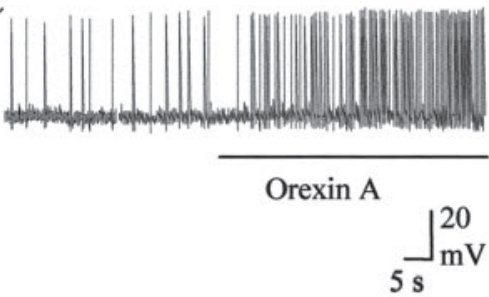

Figure 3. Presumed GABAergic neurons with low spontaneous firing rate are excited by orexins. A, Double stainings of biocytin-filled neuron (red) and TH-immunoreactive neurons (green). This neuron is TH negative. $B$, Voltage responses to current pulses $(-0.2,0,+0.1 \mathrm{pA})$. $C$, Chart recording of membrane potential and spontaneous action potentials before and after application of orexin A (100 nm).

2. Presumed GABAergic neurons with high spontaneous firing rate are excited orexins. A, Double stainings of biocytin-filled neuron (red) and TH-immunoreactive neurons (green). This neuron is TH negative. Arrows indicate the position of the neuron. B, Voltage responses to current pulses $(-0.3,0,+0.1 \mathrm{pA})$. C, Chart recording of membrane potential and spontaneous action potentials of the neuron before and after application of orexin $B(100 \mathrm{nM}) . D$, Chart recording of the membrane potential of the neuron after application of $0.5 \mu \mathrm{M}$ TTX. Orexin A causes depolarization of the cell.

both groups were hyperpolarized by the $\mu$-receptor agonist DAMGO ( $1 \mu \mathrm{M}, 6.4 \pm 1.2 \mathrm{mV}$ in "fast" and $6.1 \pm 0.8 \mathrm{mV}$ in "slow" neurons). These two groups of nondopamine cells differed in afterhyperpolarization (AHP) amplitude (10.7 \pm 0.9 vs $14 \pm 0.9 \mathrm{mV}$ in fast-firing and slow-firing cells, respectively; $p<$ $0.05)$ and spike threshold $(-52.2 \pm 0.4$ and $-49.4 \pm 0.2 \mathrm{mV}$, respectively; $p<0.005)$. Spike duration did not differ. Input resistance did not differ in dopaminergic $(266 \pm 48 \mathrm{M} \Omega ; n=14)$ and GABAergic (197 $\pm 19 \mathrm{M} \Omega ; n=6)$ cells.

The same groups of cells were found in extracellular singleunit recordings: presumed dopaminergic neurons fired at lower frequencies $(2.23 \pm 0.40 \mathrm{~Hz} ; n=25)$, had broader action poten-

tials ( $>2 \mathrm{msec}$ ), and were inhibited by the $\mathrm{D}_{2}$ receptor agonist quinpirole $(10 \mu \mathrm{M})$ or dopamine $(30 \mu \mathrm{M})$. Presumed fast-firing GABAergic neurons generally fired at higher frequencies (7.31 \pm $1.35 \mathrm{~Hz})$, had briefer action potentials $(<1.5 \mathrm{msec})$, and were unaffected by quinpirole and their firing rate was reduced by DAMGO $(1 \mu \mathrm{M})$ to $44.4 \pm 6.4 \%$ of baseline $(n=10)$. The third group of cells fired much more slowly $(0.89 \pm 0.33 \mathrm{~Hz} ; n=6)$, had the same action potential duration as fast-firing GABAergic cells, and was inhibited by DAMGO (39.4 $\pm 9.2 \%)$ but was unaffected by quinpirole $(10 \mu \mathrm{M})$ or dopamine $(30 \mu \mathrm{M})$.

\section{Responses to orexins in dopaminergic cells}

Three groups of dopaminergic cells in the VTA could be distinguished according to their response to orexin A. In 10 dopaminergic neurons tested extracellularly and four whole-cell recordings from dopaminergic neurons, there was no effect of orexin A $(100 \mathrm{~nm})$ on the firing rate or membrane potential. The applica- 
Table 1. Distribution of $m R N A$ for $T H, G A D$, orexin receptors $\left(\mathrm{OX}_{1}\right.$ and $\left.\mathrm{OX} \mathrm{X}_{2}\right), \mathrm{CB}$, and NPY in VTA neurons

\begin{tabular}{|c|c|c|c|c|c|c|c|c|c|c|c|c|c|}
\hline & \multirow[b]{2}{*}{ Soma size $(\mu \mathrm{m})$} & \multicolumn{3}{|c|}{$0 \mathrm{X}_{1}^{+} \mathrm{OX}_{2}^{+}$} & \multicolumn{3}{|c|}{$0 \mathrm{X}_{1}^{+} \mathrm{OX}{ }_{2}^{-}$} & \multicolumn{3}{|c|}{$\mathrm{OX}_{1}^{-} \mathrm{OX}_{2}^{+}$} & \multicolumn{3}{|c|}{$\mathrm{OX}_{1}^{-} \mathrm{OX}_{2}^{-}$} \\
\hline & & $n$ & $\mathrm{CB}^{+}$ & $\mathrm{NPY}^{+}$ & $n$ & $\mathrm{CB}^{+}$ & $\mathrm{NPY}^{+}$ & $n$ & $\mathrm{CB}^{+}$ & $\mathrm{NPY}^{+}$ & $n$ & $\mathrm{CB}^{+}$ & $\mathrm{NPY}^{+}$ \\
\hline $\mathrm{TH}^{+} \mathrm{GAD}^{-}(n=21)$ & $22.5 \pm 0.8$ & 9 & 6 & 4 & 7 & 5 & 4 & 0 & 0 & 0 & 5 & 0 & 1 \\
\hline $\mathrm{TH}^{+} \mathrm{GAD}^{+}(n=5)$ & $21.2 \pm 1.0$ & 1 & 0 & 1 & 3 & 0 & 1 & 1 & 0 & 1 & 0 & 0 & 0 \\
\hline $\mathrm{TH}^{-}(n=13)$ & $16.3 \pm 1.0$ & 4 & 1 & 0 & 5 & 3 & 0 & 1 & 1 & 1 & 4 & 0 & 1 \\
\hline
\end{tabular}

Neurons were divided into 12 groups according to the presence of mRNA for TH, GAD, and orexin receptors. Number of cells in each group is shown in the columns labeled $n$ and the number of cells colocalizing $C B$ or NPY in the columns $C B^{+}$ and $\mathrm{NPY}^{+}$, respectively. Some cells colocalized CB and NPY.

tion of higher concentrations of orexin A (500 nM, $n=6 ; 1 \mu \mathrm{M}$, $n=5)$ also did not influence the firing of these cells. In another group of dopamine neurons, orexin A produced an increase in firing up to $208 \pm 35 \%$ of baseline rate in extracellular recordings $(n=8)$. The generation of a concentration-response curve revealed that the $\mathrm{EC}_{50}$ for orexin-responsive neurons in the VTA was $78 \mathrm{~nm}$ (at least four neurons were tested at 10, 50, 100, 500, and $1000 \mathrm{~nm}$ ). In whole-cell recordings, increases in firing were accompanied by a moderate depolarization $(4 \pm 0.8 \mathrm{mV} ; n=5)$ (Fig. 1C). In this group of cells, orexin B caused a similar increase in firing rate $(205 \pm 43 \% ; n=4)$ and amount of depolarization in responsive cells. Two cells recorded extracellularly and one recorded in current-clamp, which had previously responded to orexin $\mathrm{A}$, did not respond to orexin $\mathrm{B}$. The previous application of the voltage-gated sodium channel blocker tetrodotoxin $(0.5$ $\mu \mathrm{M})$ did not prevent the depolarization caused by orexin $\mathrm{A}(n=$ $4)$ or orexin $\mathrm{B}(n=3)$ (Fig. $1 D)$.

In the last group of dopaminergic cells, after application of orexin A, the regular firing pattern was changed to an oscillatory one whereby periods of higher-frequency firing $(1.3-8 \mathrm{~Hz}, 5-30$ $\mathrm{sec})$ alternated with silent periods ( $1-5 \mathrm{sec})$. In extracellular recordings, 7 of 25 cells tested responded in this manner to orexin A (100 nM). Orexin B was also able to elicit this kind of response $(n=4)$. Five cells recorded in current clamp demonstrated an oscillatory response to orexin $\mathrm{B}(100 \mathrm{nM})$. In three of these five cells, strong depolarizations $(7 \pm 0.6 \mathrm{mV})$ accompanied by bursts (three to six) of action potentials were interrupted by periods of relative hyperpolarization when the cell did not fire (Fig. $1 E, F$ ). In one cell, silent periods occurred during periods of depolarization. In the final cell, silent periods did not occur, but the firing rate changed periodically from a lower rate $(0.5 \mathrm{~Hz})$ to a higher rate $(4 \mathrm{~Hz})$. All of these effects were reproduced by application of orexin B (100 nM). This last group of dopaminergic cells (showing oscillatory firing) differed from the other dopaminergic neurons in one respect only: it had a smaller $I_{\mathrm{AHP}}$ (AHP amplitude was $12.8 \pm 1.9$ vs $17.6 \pm 0.8 \mathrm{mV} ; p<0.005)$.

\section{Responses to orexins in GABAergic cells}

Both groups of presumed GABAergic cells were excited by orexins. In extracellular recordings, application of orexin A (100 nM) to the fast firing cells caused an increase in the firing frequency to $154 \pm 21 \%$ of baseline $(n=10)$. Orexin B $(100 \mathrm{nM})$ also increased the firing of these cells $(n=5)$. In whole-cell patch-clamp recordings, the application of orexins caused a depolarization of $3.7 \pm$ $0.3 \mathrm{mV}(n=3)$ (Fig. 2C). A similar amount of depolarization was seen in the presence of TTX $(n=3)$ (Fig. $2 D)$.

In extracellular recordings from the slow-firing GABAergic cells, application of orexin A (100 nM) caused a very large increase in firing rate to $700 \pm 171 \%$ of baseline $(n=6)$ (Fig. $3 C)$. Orexin $\mathrm{B}$ increased the firing rate to $570 \pm 113 \%$ of baseline $(n=3$; not significantly different from orexin A). After washout of orexins and stabilization of the firing rate, the frequency of firing was still higher than before application of orexins and did not return to the baseline level during $1 \mathrm{hr}$ of washout. In intracellular recordings, orexin A caused a depolarization of $5.0 \pm 1.6 \mathrm{mV}(n=4)$. The depolarization was not blocked by tetrodotoxin $(0.5 \mu \mathrm{M}$; $n=3)$.

\section{Responses to melanin-concentrating hormone}

$\mathrm{MCH}$ is a neuropeptide that is also expressed exclusively in the perifornical hypothalamic area and stimulates feeding (Qu et al., 1996). In extracellular recordings, the application of melaninconcentrating hormone $(1 \mu \mathrm{M})$ failed to affect the firing of dopaminergic $(n=7)$ or fast-firing GABAergic $(n=6)$ cells.

\section{Single-cell RT-PCR from acutely isolated cells}

The cytoplasm was extracted from 39 acutely isolated VTA neurons, and single-cell PCR was performed for TH, GAD, orexin receptors $\left(\mathrm{OX}_{1}\right.$ and $\left.\mathrm{OX}_{2}\right), \mathrm{CB}$, and NPY mRNA (Table 1). Recently, it has been demonstrated in mice that different functional groups of TH-positive neurons can be discriminated in the VTA according to the expression of calbindin (Neuhoff et al., 2002). Interestingly, we found that calbindin was only expressed in cells that express at least one subtype of orexin receptor and was never expressed in TH-positive cells, which were also positive for GAD (Table 1). It was expressed in $52.4 \%$ (11 of 21) of TH-positive cells and $55.6 \%$ (five of nine) of TH-negative cells that expressed orexin receptors and was never detected in cells that lacked orexin receptors. In contrast, there was no correlation between the expression of NPY and orexin receptors. $\mathrm{CB}^{+} / \mathrm{TH}^{+}$-positive cells had a soma size of $20.3 \pm 0.3 \mu \mathrm{m}(n=11)$, which was significantly smaller than for $\mathrm{CB}^{-} / \mathrm{TH}^{+}$-negative cells $(23.9 \pm 1.2 \mu \mathrm{m}$; $n=15 ; p<0.05)$. In TH-negative cells, there was no correlation between the expression of $\mathrm{CB}$ and soma size, but TH-negative neurons that expressed at least one type of orexin receptors were smaller $(14.8 \pm 1.1 \mu \mathrm{m})$ than $\mathrm{TH}$-negative cells that did not express orexin receptors $(19.5 \pm 1.0 \mu \mathrm{m} ; p<0.02)$.

\section{Discussion}

We show here using extracellular and whole-cell patch-clamp recording techniques that orexins excite the majority of neurons in the ventral tegmental area of the rat. Whereas GABAergic cells were uniformly excited, dopaminergic cells showed a variety of responses. One group of cells was unaffected by orexins, similar to our findings with dopaminergic neurons in the substantia nigra (Korotkova et al., 2002). A second group of cells showed a large increase in firing frequency that was associated with a depolarization. The depolarizing effect of orexins was not blocked by the voltage-gated sodium channel blocker tetrodotoxin and so is likely to represent a direct effect on the recorded neurons. The third group of dopaminergic cells that we encountered had their firing pattern changed by the application of orexins to periods with increased firing separated by silent periods. In whole-cell current-clamp recordings, silent periods were associated with either hyperpolarizations or large depolarizations leading to inactivation of voltage-gated sodium channels. In several cells burst 
firing was observed; burst firing is commonly observed in vivo and is associated with the unexpected appearance of rewards or stimuli-predicting reward (Schultz, 1998). In vitro, a burst-like pattern, somewhat different from "natural" bursts, can be elicited by application of nickel, alone or in combination with apamin, which blocks a slow afterhyperpolarization (Wolfart and Roeper, 2002), or by NMDA together with apamin (Seutin et al., 1993). In that regard, it is interesting that those cells that later showed oscillatory responses to orexins had a significantly reduced AHP in contrast to other dopaminergic cells. Similar to our findings in the substantia nigra (Korotkova et al., 2002), GABAergic neurons in the VTA were strongly excited by orexins. The depolarization of these cells persisted in the presence of tetrodotoxin, indicating that this was also a direct effect.

In single-cell PCR experiments, we found that both orexin receptors were expressed in VTA cells. Many cells contained only the $\mathrm{OX}_{1}$ receptor, which is consistent with our finding that occasional cells responded to orexin A but not to orexin B in slice experiments. CB was expressed in half of VTA cells that expressed orexin receptors but was never detected in cells that lacked orexin receptors. In mice, the $\mathrm{TH}^{+} / \mathrm{CB}^{+}$cells had smaller afterhyperpolarizations than $\mathrm{TH}^{+} / \mathrm{CB}^{-}$VTA neurons (Neuhoff et al., 2002), so this group of cells may correspond to the cells in which we found oscillatory responses to orexins. A subpopulation of $\mathrm{TH}^{+}$cells was also positive for GAD65; recently, the existence of such a group of cells has been demonstrated using anatomical techniques (Carr and Sesack, 2000; Gonzalez-Hernandez et al., 2001). They are likely to be excited by orexins, because we showed that they express orexin receptors.

Dopaminergic and GABAergic neurons in the VTA were excited by orexin A and orexin B and possess both types of orexin receptors, suggesting that they play a role in both the arousalnarcolepsy and feeding aspects of the function of orexins. Cataplexy is elicited in narcoleptics by emotional arousal (Nishino and Mignot, 1997). In narcoleptic dogs, which have a dysfunctional orexin type II receptor, the most commonly used assay for cataplexy is the food-elicited cataplexy test (Nishino and Mignot, 1997). Given the role played by VTA dopamine neurons in response to primary rewards such as food, dysfunction of the orexin regulation of dopamine neurons is likely to be an important component of the triggering mechanism for cataplexy (Reid et al., 1996; Okura et al., 2000). In normal individuals, the orexin modulation of VTA neurons may be important in transmitting information about the availability of primary rewards to the mesocorticolimbic reward system (Schultz, 1998). A subpopulation of orexin neurons possess leptin receptors (Willie et al., 2001), and leptin administration is known to modulate the rewarding effect of lateral hypothalamic stimulation (Fulton et al., 2000). Furthermore, orexin neurons are sensitive to metabolic state, receiving input from glucose-sensitive neurons (Liu et al., 2001). One model of the role of the orexin modulation of VTA neurons could be as follows: lack of adequate metabolic substrate would lead to increased activity in orexin neurons, excitation of dopaminergic and GABAergic neurons in the VTA, leading to increased arousal, locomotor activity, and a search for food.

\section{References}

Albanese A, Minciacchi D (1983) Organization of the ascending projections from the ventral tegmental area: a multiple fluorescent retrograde tracer study in the rat. J Comp Neurol 216:406-420.
Carr DB, Sesack SR (2000) GABA-containing neurons in the rat ventral tegmental area project to the prefrontal cortex. Synapse 38:114-123.

Cauli B, Audinat E, Lambolez B, Angulo MC, Ropert N, Tsuzuki K, Hestrin S, Rossier J (1997) Molecular and physiological diversity of cortical nonpyramidal cells. J Neurosci 17:3894-3906.

Eriksson KS, Sergeeva O, Brown RE, Haas HL (2001) Orexin/hypocretin excites the histaminergic neurons of the tuberomammillary nucleus. J Neurosci 21:9273-9279.

Fadel J, Deutch AY (2002) Anatomical substrates of orexin-dopamine interactions: lateral hypothalamic projections to the ventral tegmental area. Neuroscience 111:379-387.

Fulton S, Woodside B, Shizgal P (2000) Modulation of brain reward circuitry by leptin. Science 287:125-128.

Gonzalez-Hernandez T, Barroso-Chinea P, Acevedo A, Salido E, Rodriguez M (2001) Colocalization of tyrosine hydroxylase and GAD65 mRNA in mesostriatal neurons. Eur J Neurosci 13:57-67.

Grace AA, Onn SP (1989) Morphology and electrophysiological properties of immunocytochemically identified rat dopamine neurons recorded in vitro. J Neurosci 9:3463-3481.

Korotkova TM, Pak MA, Eriksson KS, Haas HL, Brown RE (2001) Orexins increase the firing rate of GABAergic neurons in the substantia nigra (SN) pars reticulata and ventral tegmental area (VTA) of the rat. Soc Neurosci Abstr 27:411.8.

Korotkova TM, Eriksson KS, Haas HL, Brown RE (2002) Selective excitation of GABAergic neurons in the substantia nigra of the rat by orexin/ hypocretin in vitro. Regul Pept 104:83-89.

Liu XH, Morris R, Spiller D, White M, Williams G (2001) Orexin A preferentially excites glucose-sensitive neurons in the lateral hypothalamus of the rat in vitro. Diabetes 50:2431-2437.

Nakamura T, Uramura K, Nambu T, Yada T, Goto K, Yanagisawa M, Sakurai $\mathrm{T}$ (2000) Orexin-induced hyperlocomotion and stereotypy are mediated by the dopaminergic system. Brain Res 873:181-187.

Neuhoff H, Neu A, Liss B, Roeper J (2002) I(h) channels contribute to the different functional properties of identified dopaminergic subpopulations in the midbrain. J Neurosci 22:1290-1302.

Nishino S, Mignot E (1997) Pharmacological aspects of human and canine narcolepsy. Prog Neurobiol 52:27-78.

Okura M, Riehl J, Mignot E, Nishino S (2000) Sulpiride, a D2/D3 blocker, reduces cataplexy but not REM sleep in canine narcolepsy. Neuropsychopharmacology 23:528-538.

Qu D, Ludwig DS, Gammeltoft S, Piper M, Pellymounter MA, Cullen MJ, Mathes WF, Przpek R, Kanarek R, Maratos-Flier E (1996) A role for melanin-concentrating hormone in the central regulation of feeding behaviour. Nature 380:243-247.

Reid MS, Tafti M, Nishino S, Sampathkumaran R, Siegel JM, Mignot E (1996) Local administration of dopaminergic drugs into the ventral tegmental area modulates cataplexy in the narcoleptic canine. Brain Res 733:83-100.

Schultz W (1998) Predictive reward signal of dopamine neurons. J Neurophysiol 80:1-27.

Seutin V, Johnson SW, North RA (1993) Apamin increases NMDA-induced burst-firing of rat mesencephalic dopamine neurons. Brain Res 630:341-344.

Steffensen SC, Svingos AL, Pickel VM, Henriksen SJ (1998) Electrophysiological characterization of GABAergic neurons in the ventral tegmental area. J Neurosci 18:8003-8015.

Vorobjev VS, Sharonova IN, Haas HL, Sergeeva OA (2000) Differential modulation of AMPA receptors by cyclothiazide in two types of striatal neurons. Eur J Neurosci 12:2871-2880.

Willie JT, Chemelli RM, Sinton CM, Yanagisawa M (2001) To eat or to sleep? orexin in the regulation of feeding and wakefulness. Annu Rev Neurosci 24:429-458.

Wise RA, Rompre PP (1989) Brain dopamine and reward. Annu Rev Psychol 40:191-225.

Wisor JP, Nishino S, Sora I, Uhl GH, Mignot E, Edgar DM (2001) Dopaminergic role in stimulant-induced wakefulness. J Neurosci 21:1787-1794.

Wolfart J, Roeper J (2002) Selective coupling of T-type calcium channels to SK potassium channels prevents intrinsic bursting in dopaminergic midbrain neurons. J Neurosci 22:3404-3413. 